\title{
POC-Scale Testing of an Advanced Fine Coal Dewatering Equipment/Technique
}

\author{
Quarterly Report \\ July 1 - September 30, 1997
}

Work Performed Under Contract No.: DE-AC22-94PC94155

\author{
For \\ U.S. Department of Energy \\ Office of Fossil Energy \\ Federal Energy Technology Center \\ P.O. Box 880 \\ Morgantown, West Virginia 26507-0880 \\ By \\ University of Kentucky \\ Center for Applied Energy Research \\ Lexington, Kentucky 40511
}




\section{Disclaimer}

This report was prepared as an account of work sponsored by an agency of the United States Government. Neither the United States Government nor any agency thereof, nor any of their employees, makes any warranty, express or implied, or assumes any legal liability or responsibility for the accuracy, completeness, or usefulness of any information, apparatus, product, or process disclosed, or represents that its use would not infringe privately owned rights. Reference herein to any specific commercial product, process, or service by trade

name, trademark, manufacturer, or otherwise does not necessarily constitute or imply its endorsement, recommendation, or favoring by the United States Government or any agency thereof. The views and opinions of authors expressed herein do not necessarily state or reflect those of the United States Government or any agency thereof. 


\section{TABLE OF CONTENTS}

Page

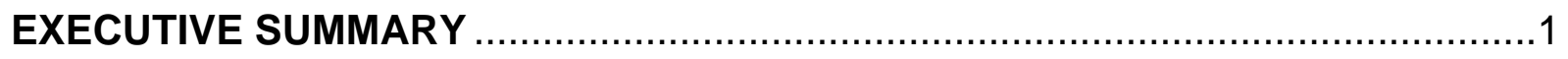

OBJECTIVES AND SCOPE OF THE PROJECT ...........................................1

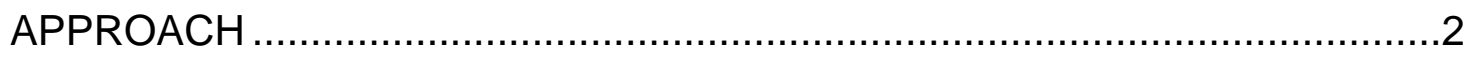

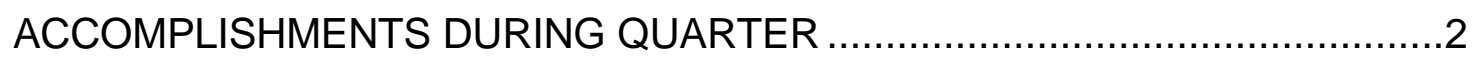

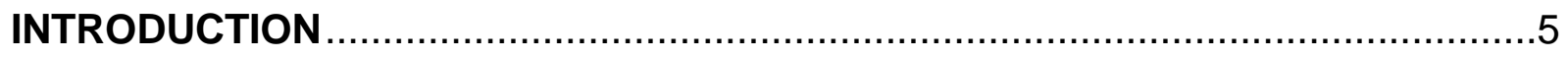

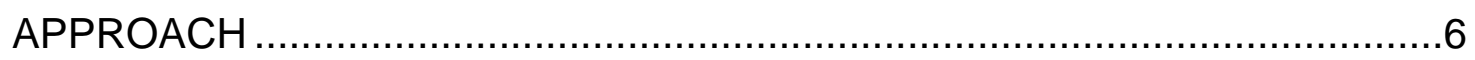

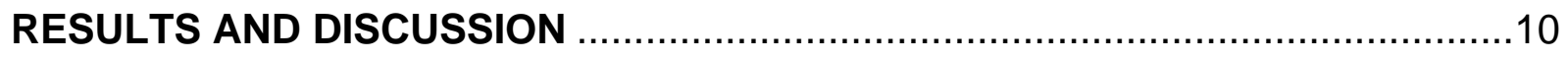

TASK 2. SAMPLE ANALYSIS AND LABORATORY TESTING ....................10

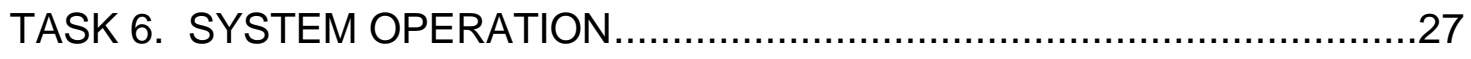

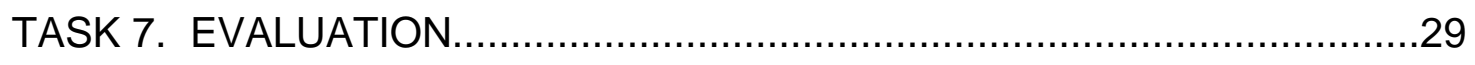

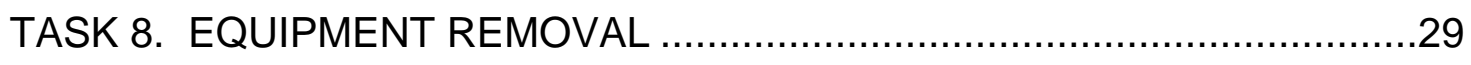

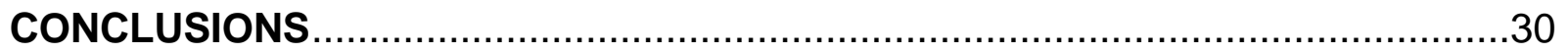

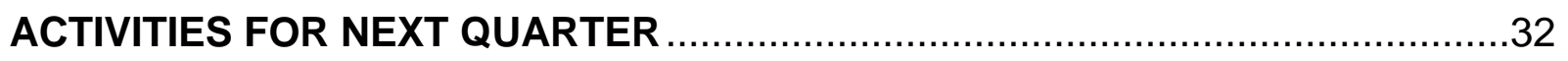




\section{LIST OF FIGURES}

Figure 1. Project management organization chart...................................

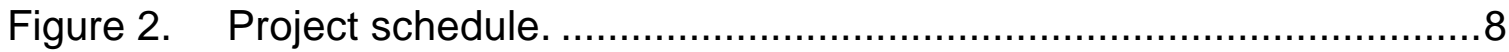

Figure 3. Effects of BASF Polymin PL on vacuum dewatering of PMCC non-compliance (high-sulfur) coal.............................................13

Figure 4. Effects of BASF Polymin PL on vacuum dewatering of PMCC compliance (low-sulfur) coal slurry conditioned in a beaker .

Figure 5. Effects of BASF Polymin PL on vacuum dewatering of PMCC compliance (low-sulfur) coal slurry conditioned in a blender. 16

Figure 6. Effects of BASF Polymin PR971 on vacuum dewatering of PMCC compliance (low-sulfur) coal slurry conditioned in a beaker.

Figure 7. Effects of BASF Polymin PR971 on vacuum dewatering of PMCC compliance (low-sulfur) coal slurry conditioned in a blender.

Figure 8. Effects of combined use of BASF Polymin PR971 and Allied Colloids Percol 156 anionic flocculant on vacuum dewatering of PMCC compliance (low-sulfur) coal slurry...

Figure 9. Effects of coal slurry conditioning time on vacuum drum filter dewatering of PMCC non-compliance (high-sulfur) coal.

Figure 10. Effects of stirrer rotation speed on vacuum drum filter dewatering of PMCC non-compliance (high-sulfur) coal.

Figure 11. Effects of drum rotation speed on vacuum drum filter dewatering of PMCC non-compliance (high-sulfur) coal. 


\section{EXECUTIVE SUMMARY}

Froth flotation technique is an effective and efficient process for recovering of ultra-fine (minus $74 \mu \mathrm{m}$ ) clean coal. Economical dewatering of an ultra-fine clean-coal product to a $20 \%$ level moisture will be an important step in successful implementation of the advanced cleaning processes. This project is a step in the Department of Energy's program to show that ultra-clean coal could be effectively dewatered to $20 \%$ or lower moisture using either conventional or advanced dewatering techniques.

The cost-sharing contract effort is for 36 months beginning September 30, 1994. This report discusses technical progress made during the quarter from July 1 - September 30, 1997.

\section{OBJECTIVES AND SCOPE OF THE PROJECT}

The main objective of the proposed program is to evaluate a novel surface modification technique, which utilizes the synergistic effect of metal ions-surfactant combination, for dewatering of ultra-fine clean coal on a proof-ofconcept scale of 1 to $2 \mathrm{tph}$. The novel surface modification technique developed at the UKCAER will be evaluated using vacuum, centrifuge, and hyperbaric filtration equipment. Dewatering tests will be conducted using the fine cleancoal froth produced by the column flotation units at the Powell Mountain Coal Company, Mayflower Preparation Plant in St. Charles, Virginia. The POC-scale studies will be conducted on two different types of clean coal, namely, highsulfur and low-sulfur clean coal. The Mayflower Plant processes coals from five 
different seams, thus the dewatering studies results could be generalized for most of the bituminous coals.

\section{APPROACH}

The project team consist of the University of Kentucky Center for Applied Energy Research (UKCAER), Powell Mountain Coal Company (PMCC) and Andritz Ruthner Inc.

The UKCAER is the prime contractor of the project which has been divided into nine (9) tasks. The clean-coal froth generated by the 'Ken-Flote' columns at the PMCC Mayflower Preparation Plant will be utilized for dewatering studies using hyperbaric, centrifuge and vacuum dewatering techniques.

\section{ACCOMPLISHMENTS DURING THE QUARTER}

Laboratory vacuum filter leaf tests have been conducted to study effects on dewatering of PMCC low-sulfur coal of two hydrophobic polymers (Polymin PR 971 and Polymin PL) obtained from BASF Corporation, Rensselaer, NY. Results have shown that dewatering effects of these reagents depended on reagent dosage and conditioning method. When coal slurry was conditioned with Polymin PR 971 in a beaker using a magnetic stirrer, use of $100 \mathrm{~g} / \mathrm{t}$ Polymin PR 971 increased cake thickness from 5.8 to $10.2 \mathrm{~mm}$ and increased cake moisture from 25.7 to $27.3 \%$. When coal slurry was conditioned with Polymin PR 971 in a blender, use of $100 \mathrm{~g} / \mathrm{t}$ Polymin PR 971 increased cake thickness from 5.8 to $6.3 \mathrm{~mm}$ and reduced cake moisture from 25.7 to $25.2 \%$. Similar results were obtained with Polymin PL. When conditioned in a beaker 
use of $100 \mathrm{~g} / \mathrm{t}$ Polymin PL increased cake thickness from 5.8 to $8.3 \mathrm{~mm}$ and slightly increased cake moisture from 25.7 to $26.7 \%$. When conditioned in a blender use of $100 \mathrm{~g} / \mathrm{t}$ Polymin PL increased cake thickness from 5.8 to $7.2 \mathrm{~mm}$ and cake moisture was essentially unchanged. In general, these two hydrophobic flocculants tested did not show very significant impacts on fine coal dewatering when compared to the results obtained previously with Allied Colloids flocculants Percol 156 and Percol 371.

Vacuum dewatering tests were also conducted using a small scale drum filter to study effects of operating parameters on fine coal filtration in the presence of flocculants. Results have shown that conditioning time, conditioning stirrer rotation speed, and drum rotation speed had significant effects on dewatering performance. As conditioning time increased from 3 to 30 minutes moisture decreased from 23.5 to $21.5 \%$ and solids throughput decreased from 208 to $97 \mathrm{~kg} / \mathrm{m}^{2} / \mathrm{hr}$ (43 to $20 \mathrm{lb} / \mathrm{ft}^{2} / \mathrm{hr}$ ), possibly due to redispersion of flocs associated with prolonged slurry stirring. As conditioning stirrer rotation speed increased from 100 to $400 \mathrm{rpm}$, cake moisture dropped from 24.8 to $22.2 \%$ and solids throughput decreased from 194 to $136 \mathrm{~kg} / \mathrm{m}^{2} / \mathrm{hr}$ (40 to $28 \mathrm{lb} / \mathrm{ft}^{2} / \mathrm{hr}$ ). Cake moisture decreased from 23.5 to $21 \%$ and solids throughput reduced from 208 to $73 \mathrm{~kg} / \mathrm{m}^{2} / \mathrm{hr}$ (43 to $15 \mathrm{lb} / \mathrm{ft}^{2} / \mathrm{hr}$ ) with increasing drum rotation speed from 1 to $6.5 \mathrm{rpm}$.

A two hour pilot scale dewatering test using the DOE/FETC Granuflow Process was conducted at the Powell Mountain Coal Co. 
s Terry eagle plant located near Summersville, W. Va. The results showed that addition of about 5.5 weight percent of orimulsion reduced filter cake moisture from 25.3 to 21.3 percent, about 10 percent total moisture reduction. The centrifuge screen effluent solids were reduced from 31.1 to 4.3 percent and ash in the effluent solids increased from 12.2 to 23.7 percent. The dust index of the product was 97 percent. The dewatered product appeared dry and easily handleable. 


\section{INTRODUCTION}

For cleaning of coal finer than $0.5 \mathrm{~mm}$ ( 28 mesh) processes based on surface chemical technique such as froth flotation and oil agglomeration are the most effective. However, the froth flotation process, which is commercially used, produces a product containing $80 \%$ moisture. The recently developed column flotation technique, which provides higher recovery of low-ash product, also suffers from the same problem of high moisture product. Dewatering of the fine coal to a low ( 20\%) moisture level using conventional filtration equipment has not been possible. This project offers a novel surface-modification approach to dewater fine coal slurry to a low moisture level using conventional and advanced dewatering equipment. The surface modification approach has provided significant reduction in filter cake moisture in laboratory studies at University of Kentucky Center for Applied Energy Research.

The aim of this program is to test the UKCAER-developed novel coal surface modification approach on a pilot scale at the rate of 1-2 tph of solids using vacuum, centrifuge and hyperbaric filtration technique. This proof-ofconcept testing is being performed at the Powell Mountain Coal Company Mayflower Plant located in St. Charles, Virginia.

The project involves a teaming arrangement between the University of Kentucky for Applied Energy Research (CAER), the Powell Mountain Coal Company (PMCC), and the Andritz Ruthner Inc. (ARI). The project will extend for a period of 36 months. 


\section{APPROACH}

A team of scientists and engineers from the Center for Applied Energy Research (UKCAER), Powell Mountain Coal Company (PMCC), and Andritz Ruthner Inc. (ARI) has been formed to accomplish the objectives of the program. Each team member brings fine-particle dewatering knowledge and experience to the project. The UKCAER, who is the prime contractor, will manage the project and will conduct the major part of the study. The PMCC will provide assistance and a facility for conducting the pilot scale tests. The ARI will conduct laboratory dewatering tests and also pilot scale tests using the hyperbaric pressure filtration unit at the PMCC. Figure 1 shows the project organization chart. The project schedule for the first two years of the program is shown in Figure 2.

The CAER collected clean-coal froth samples from the Mayflower plant for the laboratory studies. Samples of clean-coal slurries were also sent to ARI for studies using their laboratory scale hyperbaric unit. At both organizations, emphasis will be given to identify optimum process and operating conditions using vacuum and pressure techniques to dewater the clean-coal slurry to about $20 \%$ level moisture. It is believed that the proposed research can achieve low moisture product on a pilot scale to the same extent which has already been achieved in laboratory studies.

The basic components of the process has been tested in the laboratory. The purpose of the proposed work here is to evaluate all of the component steps 


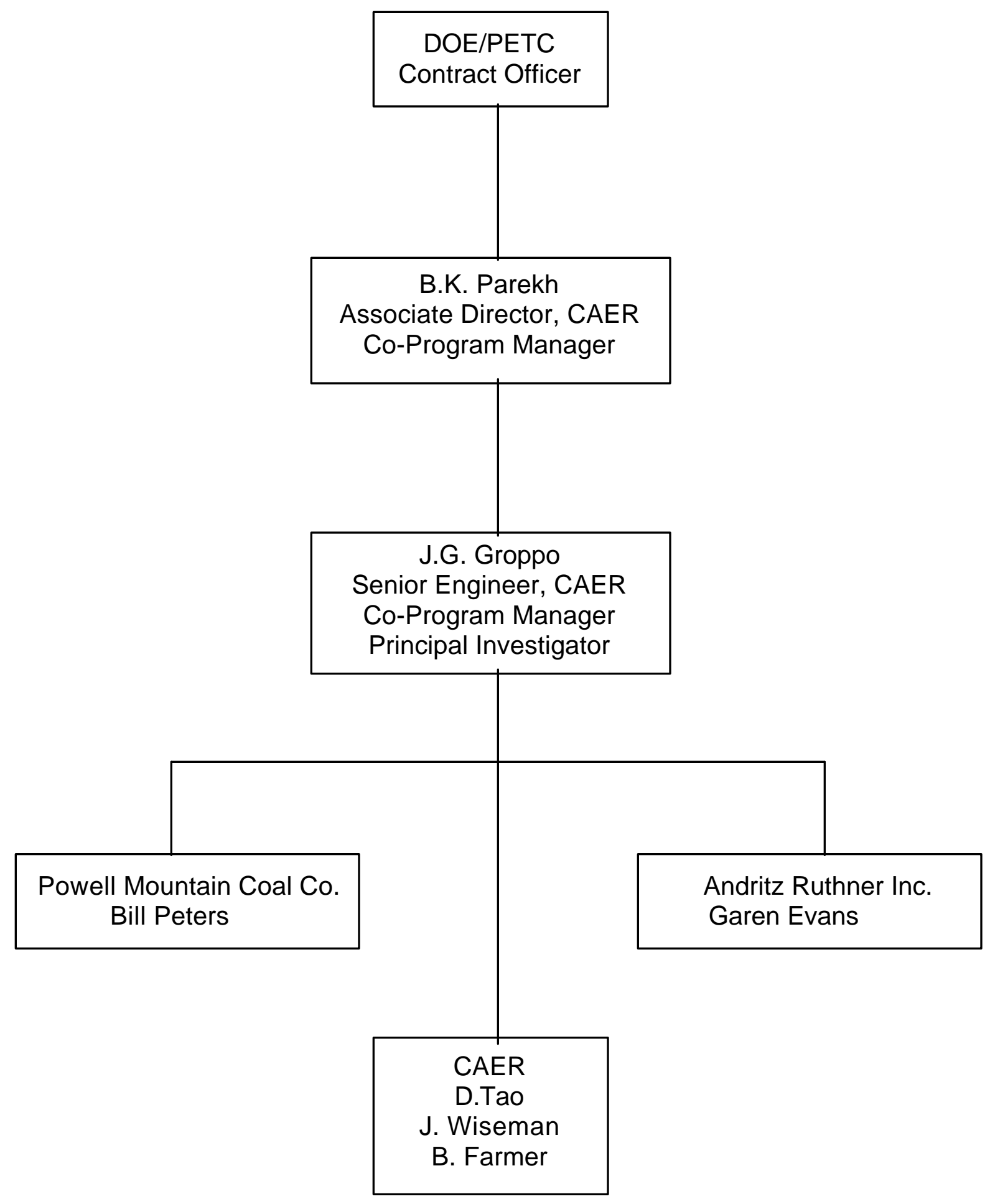

Figure 1. Project management organization chart 


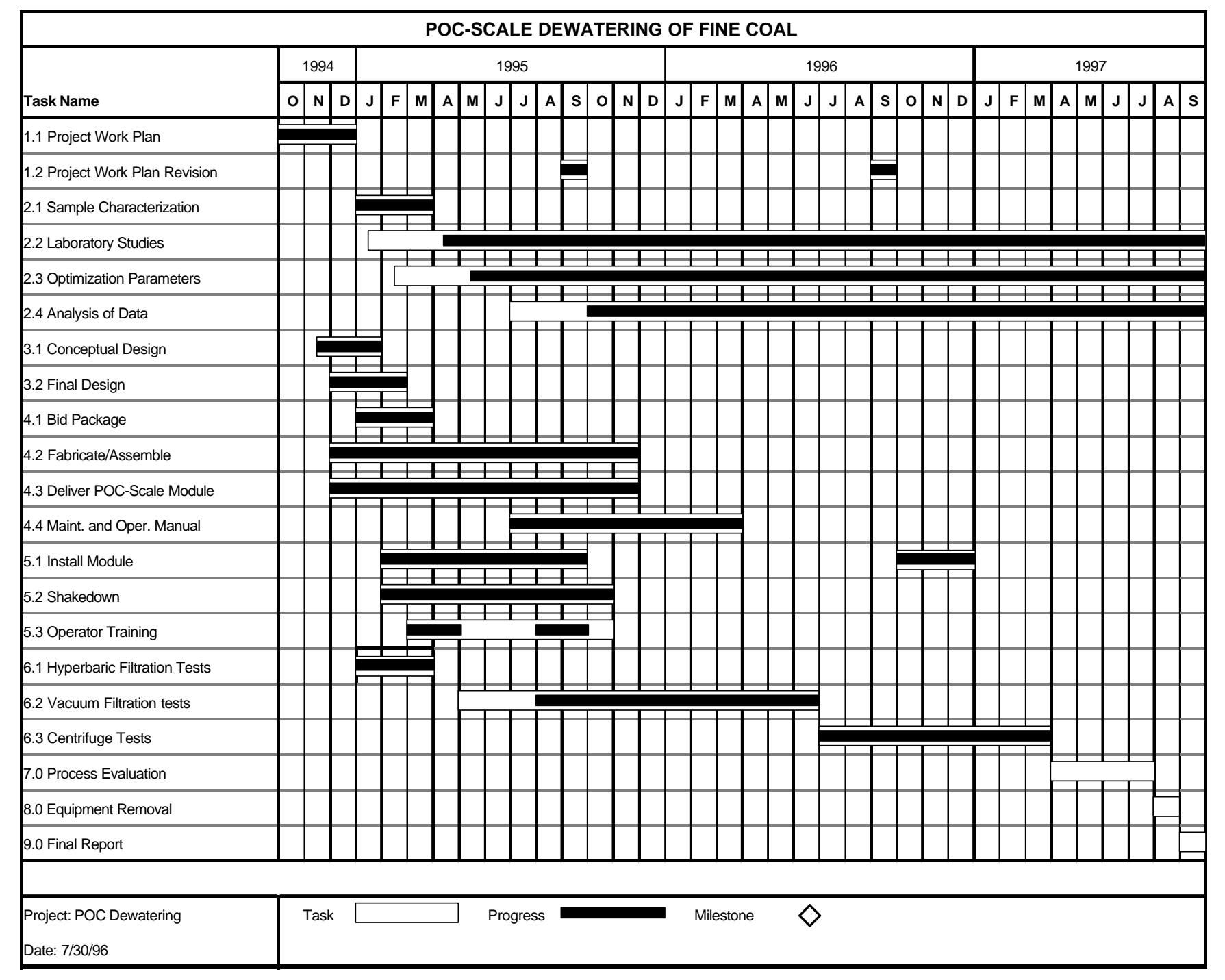

Figure 2 Up-to-date project schedule 
on a consistent basis, and, to the extent possible in laboratory studies, demonstrate the feasibility of their integration. The outcome of this program will be to identify a process/technique combination which is able to achieve a $20 \%$ or lower moisture in the fine clean coal product and to provide technical and economic evaluations of the integrated concept in sufficient detail for a coal company to decide to install the dewatering process in their plant. 


\section{RESULTS AND DISCUSSION}

The project has been divided into tasks and subtasks listed in Table 1. Each task and subtask has specific objective which can be inferred from its title. During this quarter (July 1 to September 30,1997 ) work was done on Tasks 2, 6,7 and 8.

\section{Task 2. Sample Analysis and Laboratory Testing:}

The laboratory dewatering tests were conducted using both compliance (low-sulfur) and non-compliance (high-sulfur) clean-coal slurries obtained from the Powell Mountain Coal Co. The low-sulfur and high-sulfur clean-coal froth slurry had the $D_{50}$ (median size) of 29.5 and $37.3 \mu \mathrm{m}$ and solids concentration about 15 and $20 \%$, respectively. The proximate analysis of both coals showed that PMCC low-sulfur coal contained $5.72 \%$ ash, $31.70 \%$ volatile matter, $69.78 \%$ fixed carbon and PMCC high-sulfur coal had $5.58 \%$ ash, $33.05 \%$ volatile matter, and $59.77 \%$ fixed carbon.

\section{Vacuum Dewatering}

During the past quarter laboratory vacuum dewatering tests were conducted with PMCC compliance (low-sulfur) and non-compliance (high-sulfur) clean-coal slurries. The objective of this work was to develop new approaches to enhance dewatering of fine coal slurry using vacuum filtration. This objective was accomplished by investigating the effects of various reagents on vacuum dewatering performance with both coal slurry samples under predetermined 
Table 1. Outline of Work Breakdown Structure

Task 1. Project Work Planning

Subtask 1.1 Project Work Plan

Subtask 1.2 Project Work Plan Revisions

Task 2. Samples Analysis and Laboratory Testing

Subtask 2.1 Acquisition and Characterization of Samples

Subtask 2.2 Laboratory Scale Testing

Subtask 2.3 Optimization of Parameters

Subtask 2.4 Analysis of Data

Task 3. Engineering Design

Subtask 3.1 Conceptual Design Package

Subtask 3.2 Final Design Package

Subtask $3.3 \quad$ Construction Schedule

Task 4. Procurement and Fabrication

Subtask 4.1 Bid Packages

Subtask 4.2 Fabricate/Assemble Components

Subtask 4.3 Deliver POC-Scale Module and Install

Subtask 4.4 Maintenance and Operating Manual

Task 5. Installation and Shakedown

Subtask 5.1 Install and Tie-in Module

Subtask 5.2 Startup Procedures/Shakedown

Subtask $5.3 \quad$ Operators Training

Task 6. System Operation

Subtask 6.1 Test Coal No. 1

Subtask 6.2 Test Coal No. 2

Task 7. Process Evaluation

Task 8. Equipment Removal

Task 9. Reporting

Subtask 9.1 Monthly Reports

Subtask 9.2 Project Final Report 
operating conditions. The reagents used in this work are believed to enhance coal dewatering by modifying the coal surface to provide favorable dewatering characteristics such as:

- high hydrophobicity

- low surface tension

- large aggregate size

- high permeability of filter cake, etc.

Reagents tested using vacuum filter included anionic (sodium 2ethylhexyl sulfate), nonionic (octyl phenoxy polyethoxy ethanol), and cationic (1hexadecyl pyridium chloride) surfactants; anionic Percol 156 and cationic Percol 371 flocculants; trivalent and divalent metal ions $\left(\mathrm{Al}^{3+}\right.$ and $\left.\mathrm{Cu}^{2+}\right)$. In the last quarter major efforts were devoted to the investigation of hydrophobic polymers, i.e., Polymin PR 971 (a proprietary polymer) and Polymin PL (a homopolymer), obtained from BASF Corporation, Rensselaer, NY and drum filter operating parameters on fine coal dewatering performance. Polymin PR 971 and Polymin PL are both commercial products sold as dewatering aids.

Vacuum Filter leaf Dewatering Tests with Hydrophobic Polymers

Figure 3 shows effects of BASF supplied Polymin PL on cake thickness and moisture obtained with the PMCC non-compliance (high-sulfur) coal. The coal slurry was conditioned with the reagent in a beaker for 3 minutes prior to filtration. The results show that cake thickness reached the maximum of about 


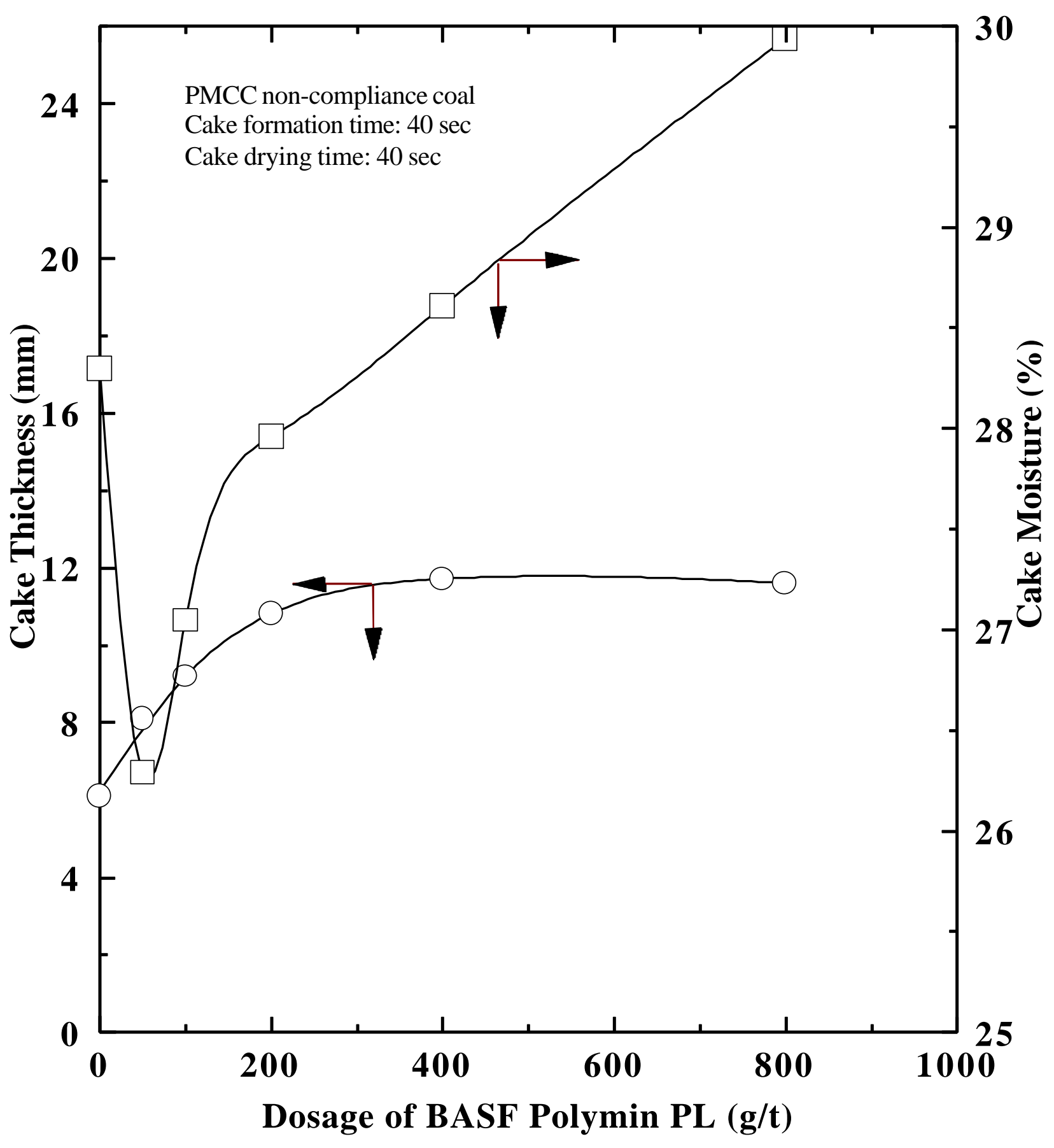

Figure 3. Effects of BASF Polymin PL on vacuum dewatering of PMCC noncompliance (high-sulfur) coal 
$12 \mathrm{~mm}$ at a dosage of $400 \mathrm{~g} / \mathrm{t}$ while the lowest cake moisture of $26.3 \%$ was achieved at a dosage of $50 \mathrm{~g} / \mathrm{t}$. Note, cake moisture increased to $30.0 \%$ with increasing polymer dosage to $800 \mathrm{~g} / \mathrm{t}$ although cake thickness leveled out at 12 $\mathrm{mm}$ at a dosage of $400 \mathrm{~g} / \mathrm{t}$. This indicated that an excessive dosage of polymer was detrimental for fine coal dewatering.

Figure 4 shows the dewatering results obtained with the PMCC compliance (low-sulfur) clean-coal slurry as a function of Polymin PL dosage. The coal slurry was conditioned with the reagent in a beaker. Cake thickness increased from 5.8 to $8.6 \mathrm{~mm}$ with increasing reagent dosage from 0 to $100 \mathrm{~g} / \mathrm{t}$. Cake moisture slightly increased with reagent dosage, from $25.7 \%$ in the baseline test to $26.7 \%$ at a dosage of $100 \mathrm{~g} / \mathrm{t}$. Compared with the results obtained with Allied Colloid cationic flocculant Percol 371 and anionic flocculant Percol 156, BASF Polymin PL showed less significant effects on fine coal dewatering.

Figure 5 shows the dewatering results obtained with PMCC low-sulfur coal conditioned with Polymin PL in a blender for 1 minute. The blender was used to provide more energy-intensive mixing conditions, and thus better adsorption of hydrophobic polymer on coal surface. Data in Figure 5 indicated that in comparison with Figure 4 cake thickness was lower at the same dosage of polymer and cake moisture was in general slightly lower. For example, at the reagent dosage of $100 \mathrm{~g} / \mathrm{t}$ cake thickness and cake moisture were $7.2 \mathrm{~mm}$ and $26.1 \%$, respectively, when the blender was used. Cake thickness and moisture 


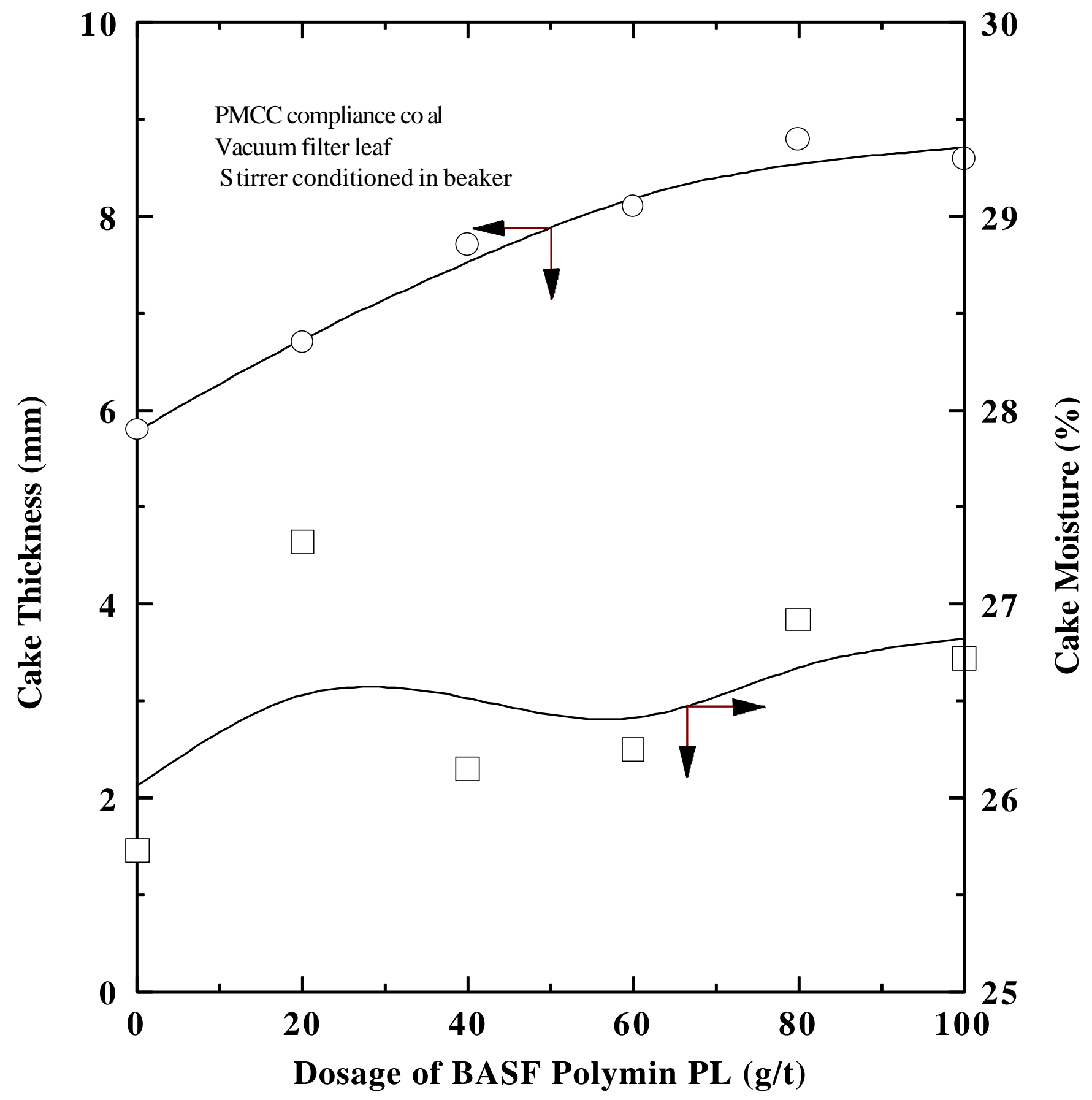

Figure 4. Effects of BASF Polymin PL on vacuum dewatering of PMCC compliance (low-sulfur) coal slurry conditioned in a beaker 


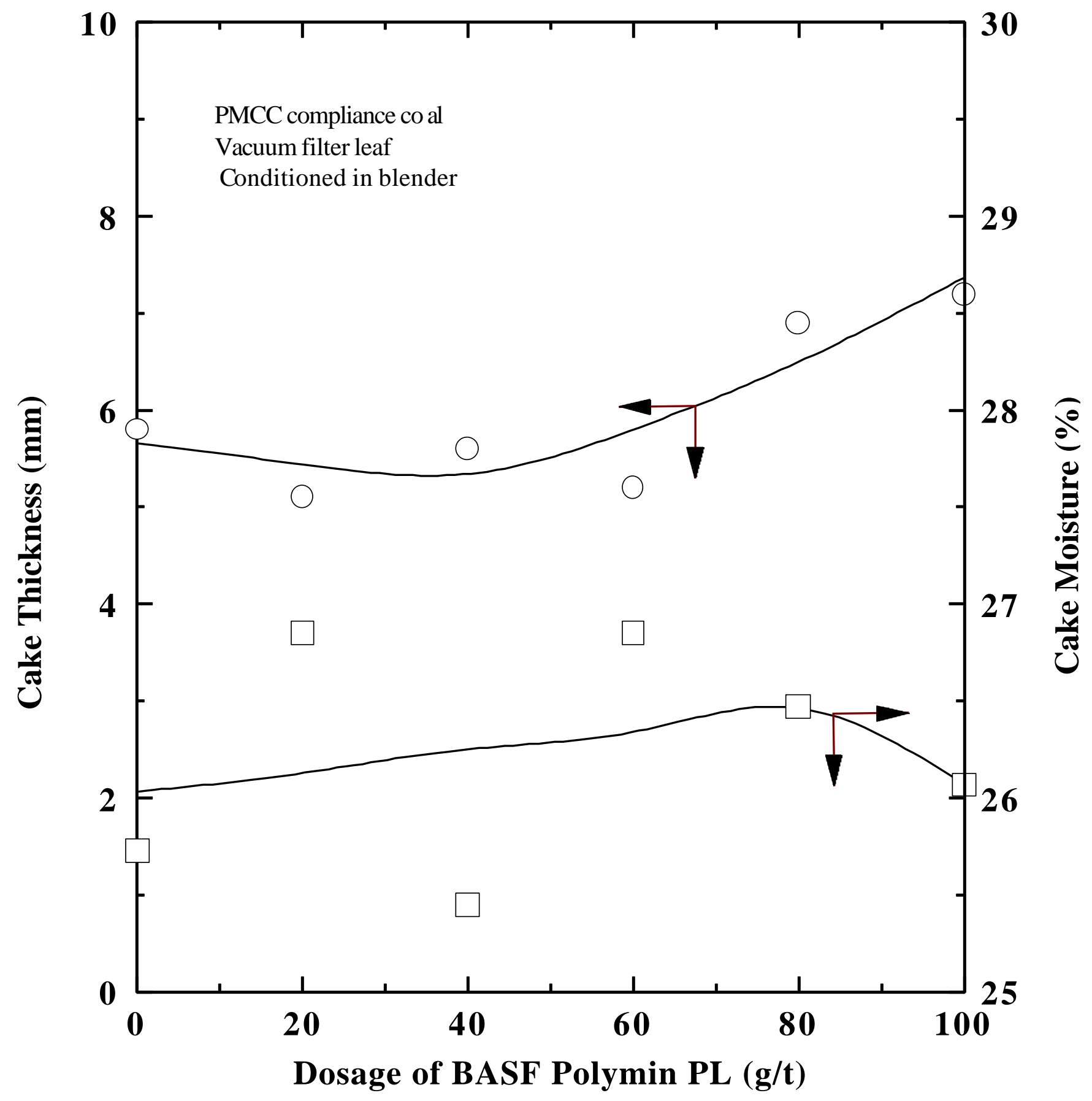

Figure 5. Effects of BASF Polymin PL on vacuum dewatering of PMCC compliance (low-sulfur) coal slurry conditioned in a blender 
were $8.6 \mathrm{~mm}$ and $26.7 \%$, respectively, when a magnetic stirrer in a beaker was used for conditioning. The reduced cake thickness under more turbulent conditions in the blender may be caused by breakage of flocs.

Figure 6 shows effects of BASF Polymin PR 971 on cake thickness and moisture for PMCC compliance (low-sulfur) coal conditioned in a magnetic bar stirred beaker. Cake thickness increased from 5.9 to $10.1 \mathrm{~mm}$ with increasing reagent dosage from 0 to $100 \mathrm{~g} / \mathrm{t}$. Compared with results obtained with Polymin PL shown in Figure 4, this increase in cake thickness was more significant. Cake moisture increased with increasing polymer dosage. But change in moisture was marginal (about one absolute percentage point) in most cases except at the dosage of $100 \mathrm{~g} / \mathrm{t}$ at which cake moisture was 1.6 percentage points higher. In comparison the cake moisture obtained with Polymin PR 971 was close to data shown in Figure 4 for Polymin PL.

Figure 7 shows effects of BASF Polymin PR 971 on cake thickness and moisture for PMCC compliance (low-sulfur) clean-coal slurry conditioned in a blender. As the reagent dosage increased cake thickness decreased initially from $5.8 \mathrm{~mm}$ with no addition of reagent to $4.7 \mathrm{~mm}$ at a dosage of $40 \mathrm{~g} / \mathrm{t}$. This was followed by gradual increase in cake thickness with further increase in the reagent dosage. At $100 \mathrm{~g} / \mathrm{t}$ cake thickness was $6.7 \mathrm{~mm}$. In comparison with results in Figure 6 obtained with the slurry conditioned in a magnetic bar stirred beaker cake thickness was much smaller when slurry was conditioned in a 


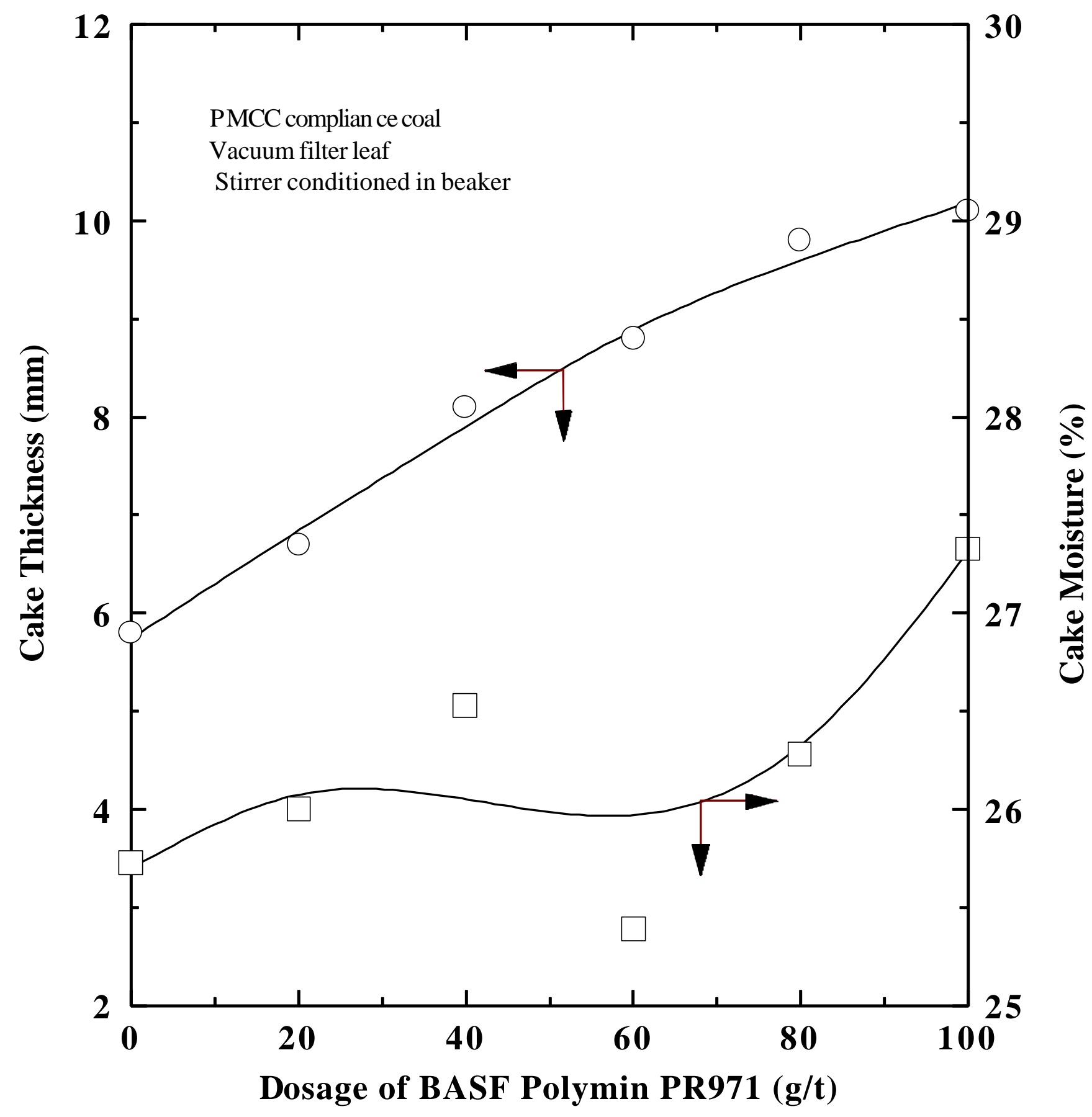

Figure 6. Effects of BASF Polymin PR971 on vacuum dewatering of PMCC compliance (low-sulfur) coal slurry conditioned in a beaker 


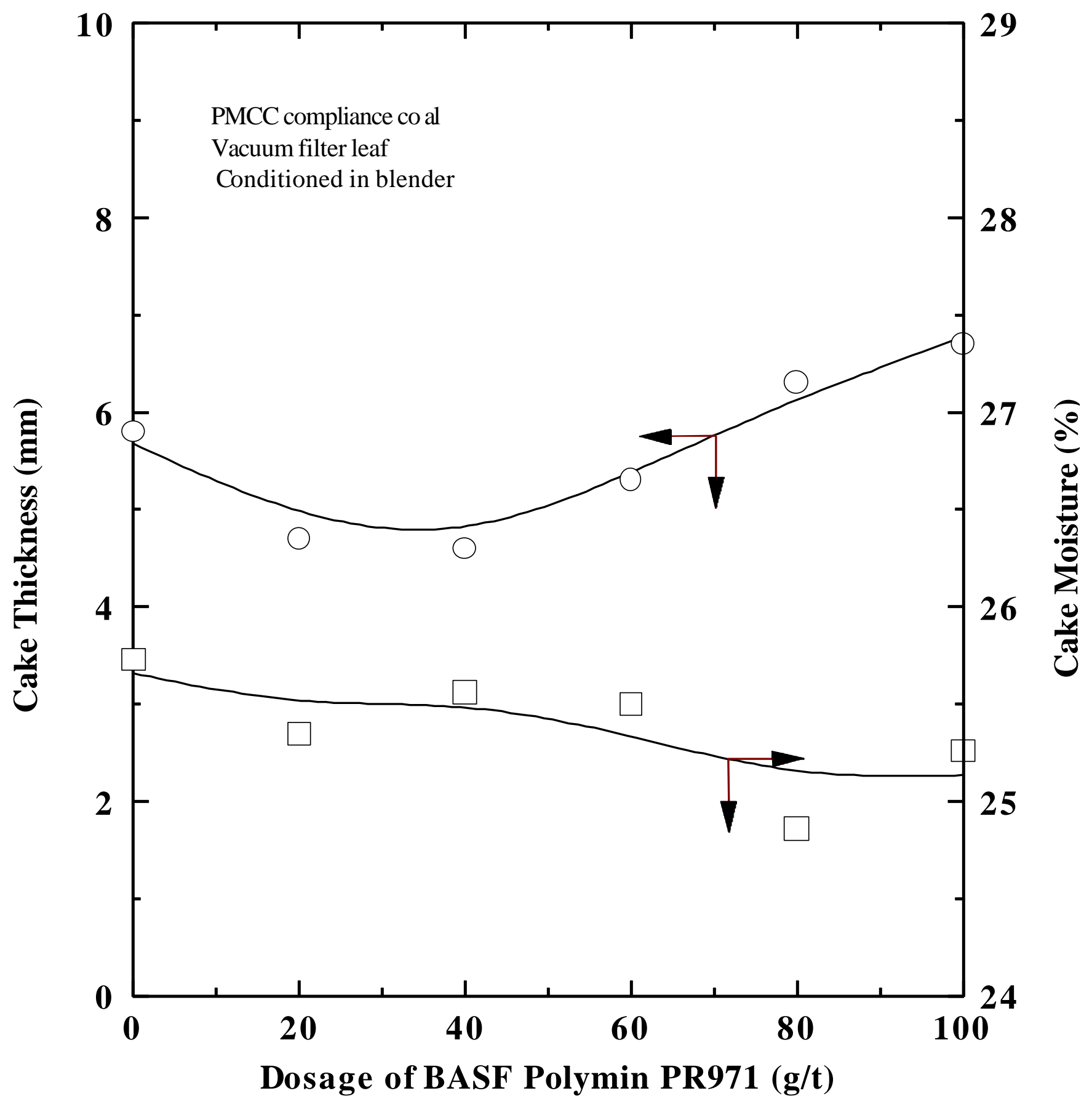

Figure 7. Effects of BASF Polymin PR971 on vacuum dewatering of PMCC compliance (low-sulfur) coal slurry conditioned in a blender 
blender. This difference in cake thickness may be attributed to difficulty in floc formation under turbulent conditions in the blender. In fact it was observed that flocs formed in the slurry after conditioning in the blender were considerably smaller than those produced after conditioning in a beaker.

Figure 7 shows a gradual but consistent decrease in cake moisture with increasing Polymin PR971. This is in contrast with Figure 6 that shows increase in cake moisture when slurry was conditioned in a beaker with the same reagent. This behavior is also different from Figure 5 that shows increase in cake moisture when slurry was conditioned with Polymin PL in the same blender. The lowest moisture of $24.8 \%$ was obtained at a dosage of $80 \mathrm{~g} / \mathrm{t}$ Polymin PR971 in Figure 7.

A number of tests were conducted to study possible synergetic effects between hydrophobic flocculant (BASF Polymin PR971) and conventional hydrophilic polymer (Allied Colloids Percol 156, anionic flocculant) on fine coal dewatering with PMCC compliance (low-sulfur) coal. Coal slurry conditioning was performed in a blender with Polymin PR971 for one minute and in a beaker with Percol 156 for three minutes. Polymin PR971 was used to enhance surface hydrophobicity of coal and Percol 156 was added to increase the size of flocs. The results of cake thickness and cake moisture are shown in Figure 8 as a function of dosage of anionic flocculant (AF). For the purpose of comparison, one series of tests were conducted with anionic flocculant only. The other series 


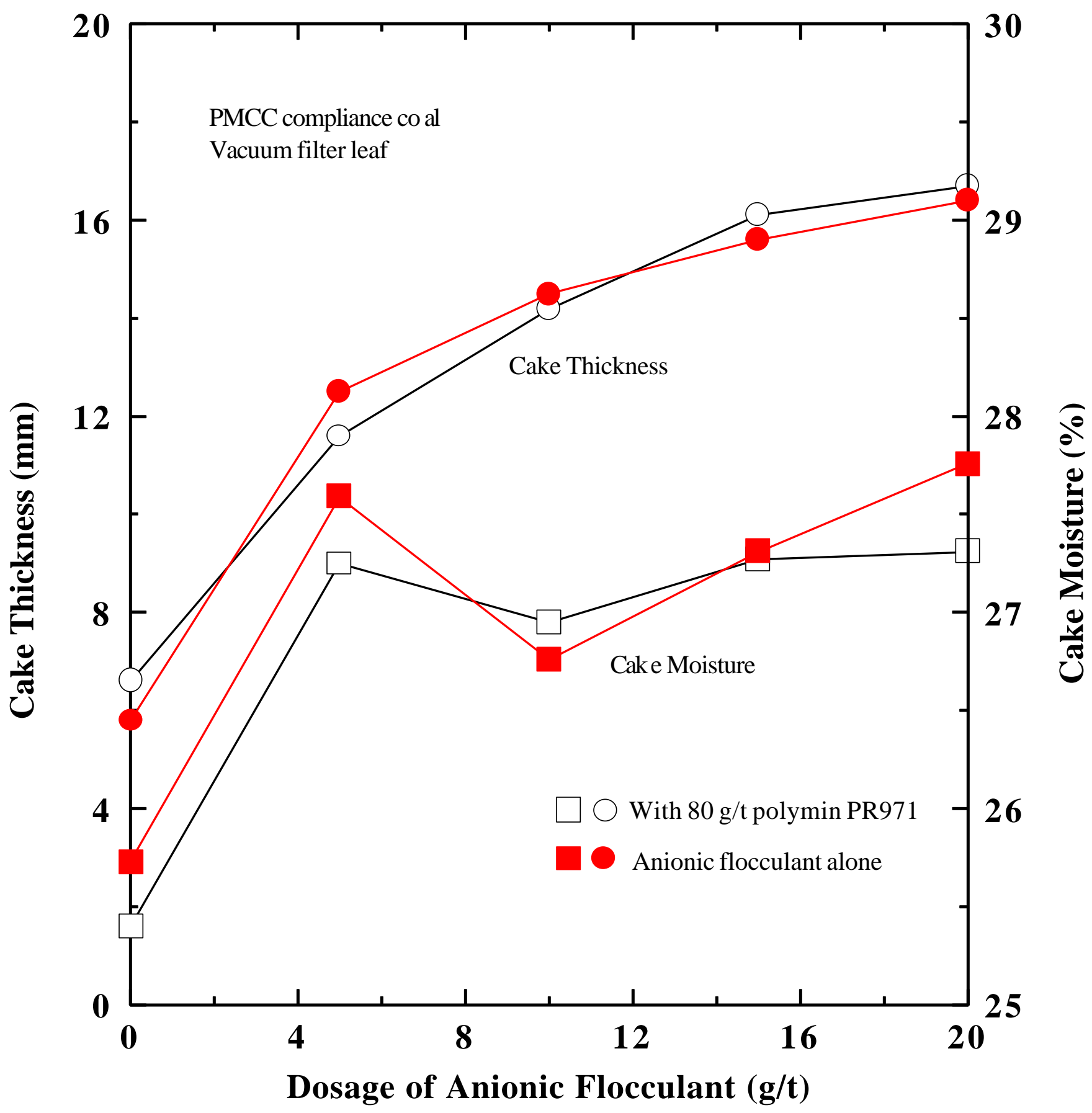

Figure 8. Effects of combined use of BASF Polymin PR971 and Allied Colloids Percol 156 anionic flocculant on vacuum dewatering of PMCC compliance (low-sulfur) coal slurry 
of tests were performed with a constant dosage of $80 \mathrm{~g} / \mathrm{t}$ Polymin PR971 and varying dosage of anionic flocculant. Figure 8 shows that use of Polymin PR971 along with the flocculant increased cake thickness with increasing anionic flocculant dosage. However, the cake moisture did not increase at higher ( $>5$ $\mathrm{g} / \mathrm{t}$ ) dosage of the flocculant. The difference in cake thickness and moisture generated by use of Polymin PR971 was not significant. This suggests that anionic flocculant Percol 156 played a dominant role in fine coal dewatering.

\section{Effects of Operating Parameters on Vacuum Drum Filter Dewatering Tests}

Figure 9 shows effects of conditioning time on solids throughput and cake moisture for PMCC non-compliance (high-sulfur) coal with a continuous vacuum drum filter. A 5 gallon bucket was used as the conditioning cell. The stirrer rotation speed was set constant at $200 \mathrm{rpm}$. A $20 \mathrm{~g} / \mathrm{t}$ anionic flocculant (Allied Colloids Percol 156) was used in all tests. As can be seen in Figure 9, the solids throughput and cake moisture decreased significantly with increasing conditioning time. At 3 minute conditioning time solids throughput and cake moisture were $208 \mathrm{~kg} / \mathrm{m}^{2} / \mathrm{hr}\left(43 \mathrm{lb} / \mathrm{ft}^{2} / \mathrm{hr}\right)$ and $23.6 \%$, respectively. At 15 minute conditioning time they were reduced to $111 \mathrm{~kg} / \mathrm{m}^{2} / \mathrm{hr}\left(23 \mathrm{lb} / \mathrm{ft}^{2} / \mathrm{hr}\right)$ and $21.7 \%$, respectively. Further increase in conditioning time did not show significant impacts on solids throughput and cake moisture. The decrease in solids throughput with increasing conditioning time can be attributed to re-dispersion of flocs as a result of prolonged stirring. 


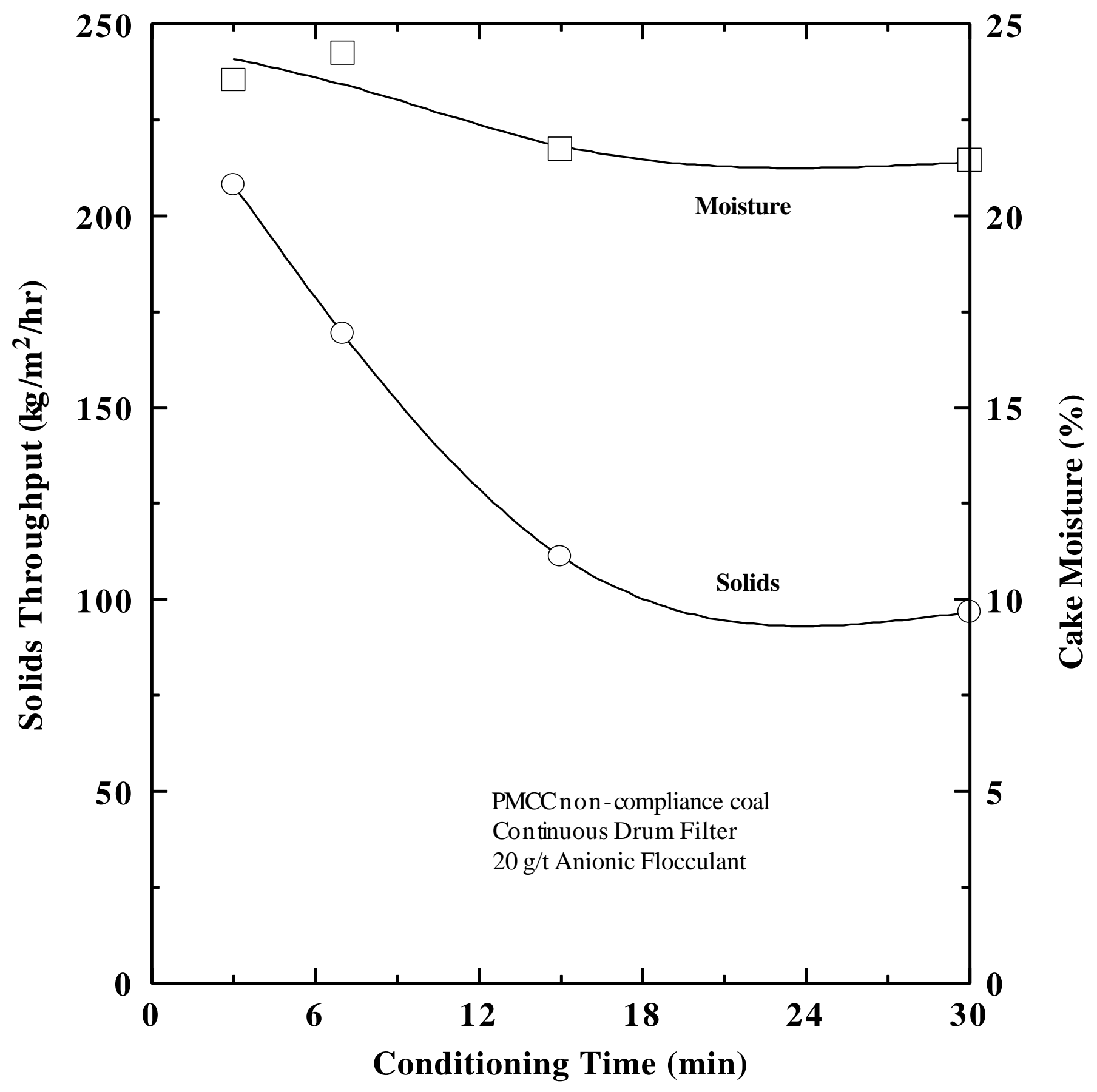

Figure 9. Effects of coal slurry conditioning time on vacuum drum filter dewatering of PMCC non-compliance (high-sulfur) coal 
Cake moisture reduction with increase in conditioning time may be due to reduced cake thickness that was also responsible for solids throughput reduction. The sharply decreasing solids throughput and much less significant reduction in cake moisture with increasing conditioning time indicated that prolonged conditioning time had adverse effects on fine coal vacuum dewatering.

Figure 10 shows effects of stirrer rotation speed on solids throughput and cake moisture. At $100 \mathrm{rpm}$ vortex formed as a result of stirring was hardly visible in the conditioning bucket. At $200 \mathrm{rpm}$ stirring was sufficiently vigorous to form a fairly deep vortex. At $300 \mathrm{rpm}$ the vortex was deepened to the bottom of the bucket. As the stirrer rotation speed increased from 100 to $200 \mathrm{rpm}$ solids throughput increased from 194 to $208 \mathrm{~kg} / \mathrm{m}^{2} / \mathrm{hr}$ (40 to $43 \mathrm{lb} / \mathrm{ft}^{2} / \mathrm{hr}$ ). But further increase in rotation speed reduced solids throughput. On the other hand cake moisture decreased consistently from $24.8 \%$ to $22.2 \%$ with increasing rotation speed from 100 to $400 \mathrm{rpm}$. The results indicated that stirrer rotation speed had significant effects on solids throughput and cake moisture. The rotation speed of stirrer should be kept constant in order to obtain reproducible dewatering results.

Drum rotation speed is an important operating parameter for vacuum drum filtration. It determines the cake formation time and cake drying time, and consequently cake thickness. Figure 11 shows effects of drum rotation speed 


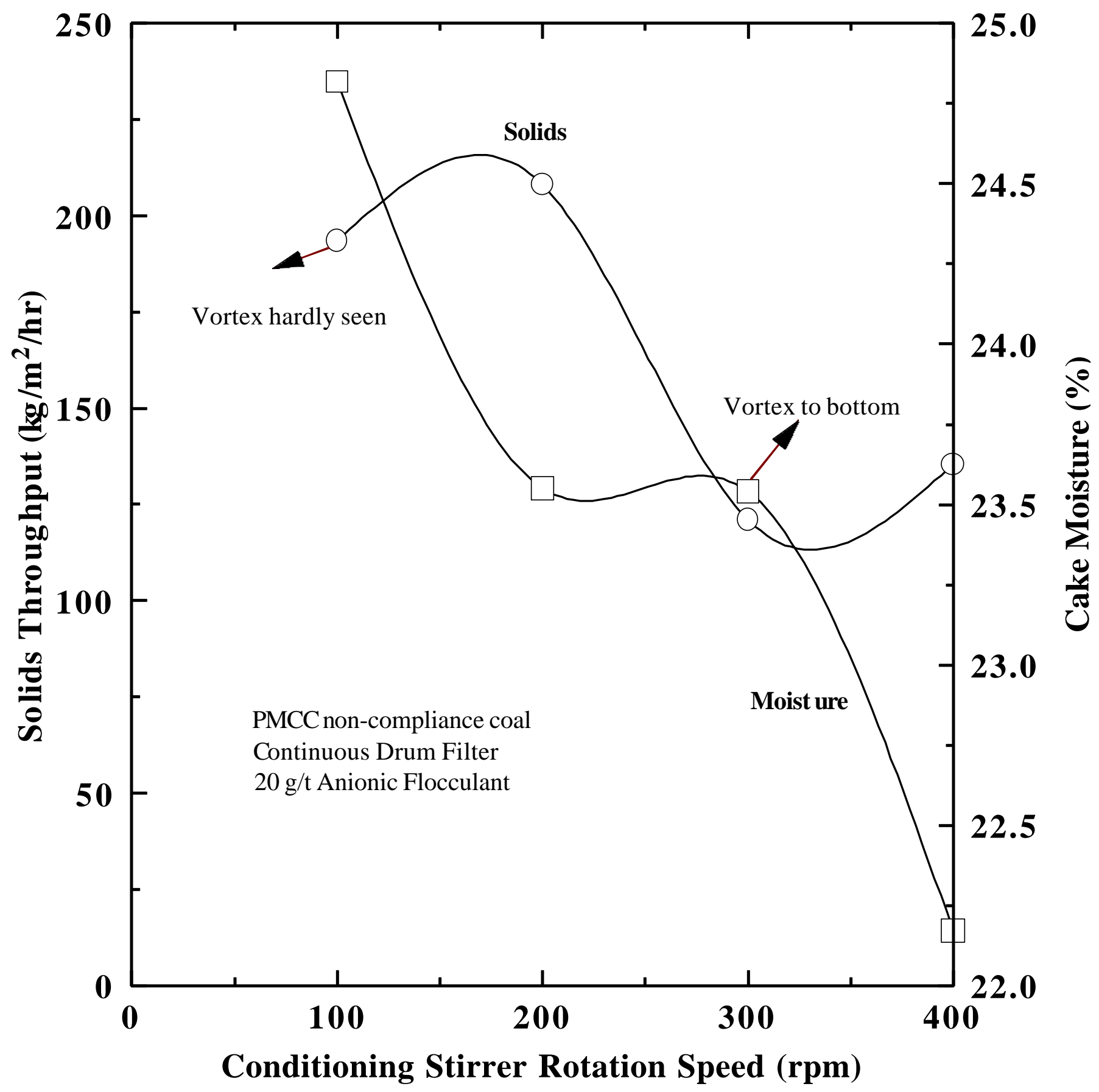

Figure 10. Effects of stirrer rotation speed on vacuum drum filter dewatering of PMCC non-compliance (high-sulfur) coal. 


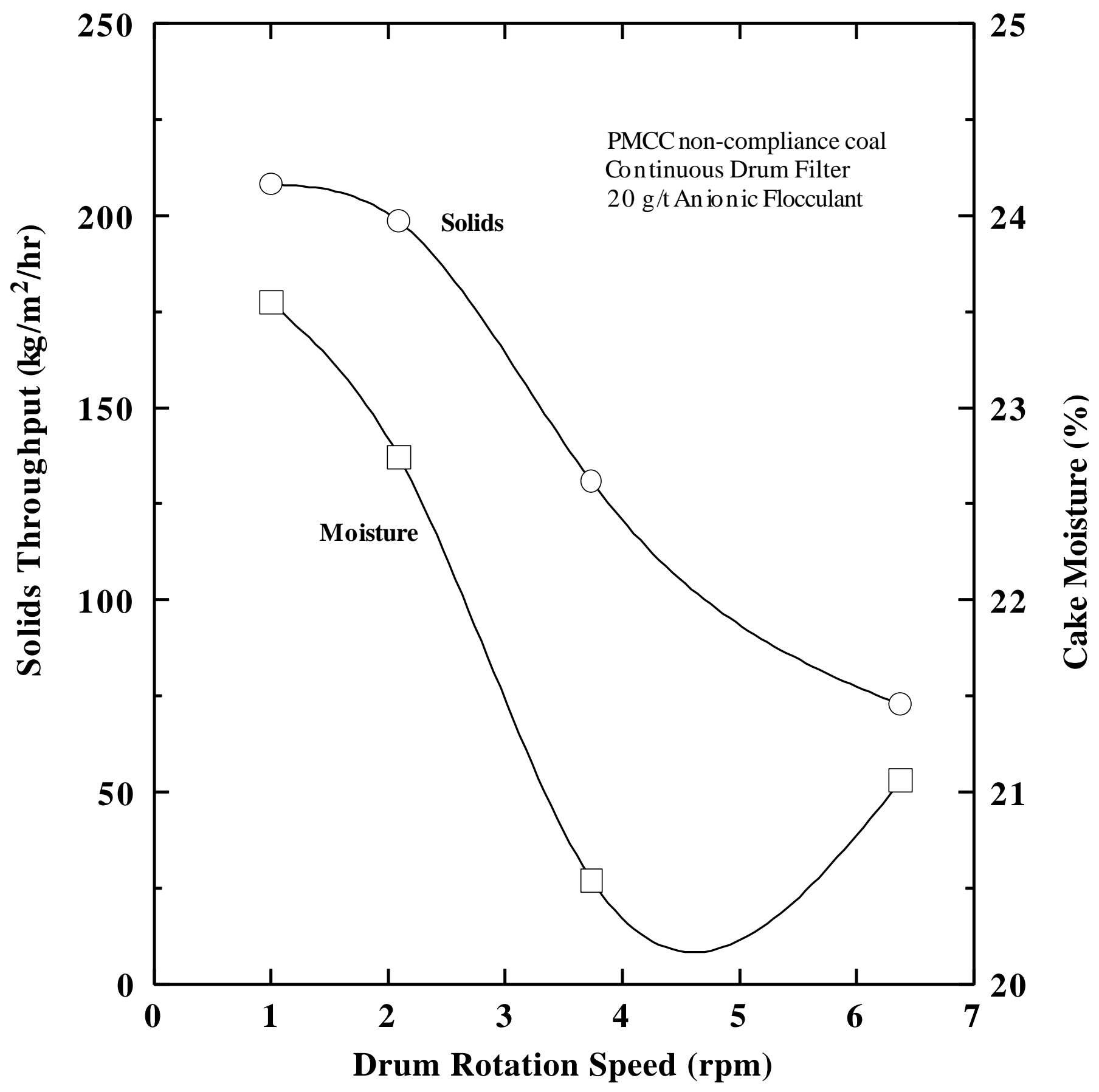

Figure 11. Effects of drum rotation speed on vacuum drum filter dewatering of PMCC non-compliance (high-sulfur) coal 
on solids throughput and cake moisture in the presence of $20 \mathrm{~g} / \mathrm{t}$ anionic flocculant (Allied Colloids Percol 156). Solids throughput decreased slowly from 208 to $198 \mathrm{~kg} / \mathrm{m}^{2} / \mathrm{hr}$ (43 to $41 \mathrm{lb} / \mathrm{ft}^{2} / \mathrm{hr}$ ) with increasing drum rotation speed from 1 to $2 \mathrm{rpm}$. Further increase in drum rotation speed had more drastic effects on solids throughput. At drum rotation speed of $3.8 \mathrm{rpm}$, solids throughput was reduced to $131 \mathrm{~kg} / \mathrm{m}^{2} / \mathrm{hr}\left(27 \mathrm{lb} / \mathrm{ft}^{2} / \mathrm{hr}\right)$. Cake moisture also decreased with increasing drum rotation speed. At one rpm drum rotation speed cake moisture was $23.5 \%$. At $3.8 \mathrm{rpm}$ cake moisture was reduced to about $20.5 \%$. This moisture was significantly lower than $27 \%$ produced in the absence of flocculant at drum rotation speed of $1 \mathrm{rpm}$. It should be emphasized that at $3.8 \mathrm{rpm}$ drum rotation speed the solids throughput shown in Figure 11 was $131 \mathrm{~kg} / \mathrm{m}^{2} / \mathrm{hr}(27$ $\left.\mathrm{lb} / \mathrm{ft}^{2} / \mathrm{hr}\right)$, substantially higher than $48 \mathrm{~kg} / \mathrm{m}^{2} / \mathrm{hr}\left(10 \mathrm{lb} / \mathrm{ft}^{2} / \mathrm{hr}\right)$ obtained in the absence of anionic flocculant at drum rotation speed of $1 \mathrm{rpm}$. These results suggest that use of flocculant in vacuum drum filter can simultaneously achieve both significant increase in solids throughput and remarkable reduction in cake moisture. With an appropriate dosage of flocculant and a suitable drum rotation speed a cake moisture of about $20 \%$ can be achieved with PMCC high-sulfur coal.

\section{Task 6. System Operation:}

Based on the encouraging pilot scale dewatering test results obtained at the PMCC Mayflower preparation plant using the DOE/FETC Granuflow Process with the consent of the Powell Mountain Coal Co. the Granuflow was evaluated on a large scale at the Terry Eagle coal preparation plant. Terry Eagle currently 
combines flotation concentrate with the classifying cyclone underflow and dewater it using a screen bowl centrifuge.

For the Granuflow tests, the orimulsion was added to the flotation concentrate. The test results are summarized in Table 2 with the orimulsion dosages of $0,0.7,2.3$ and 5.5 weight percent, the product moisture of the clean coal was 25.3, 25.0, 22.2, and 21.3 percent, respectively. The orimulsion treated product appeared to be drier on the conveyor belt and its handleability appeared to be markedly improved.

Table 2. Granuflow Process test results on a 36-inch Bird screen-bowl centrifuge with a feed slurry of a mixture of flotation concentrate and cyclone underflow from the Terry Eagle coal preparation plant in West virginia

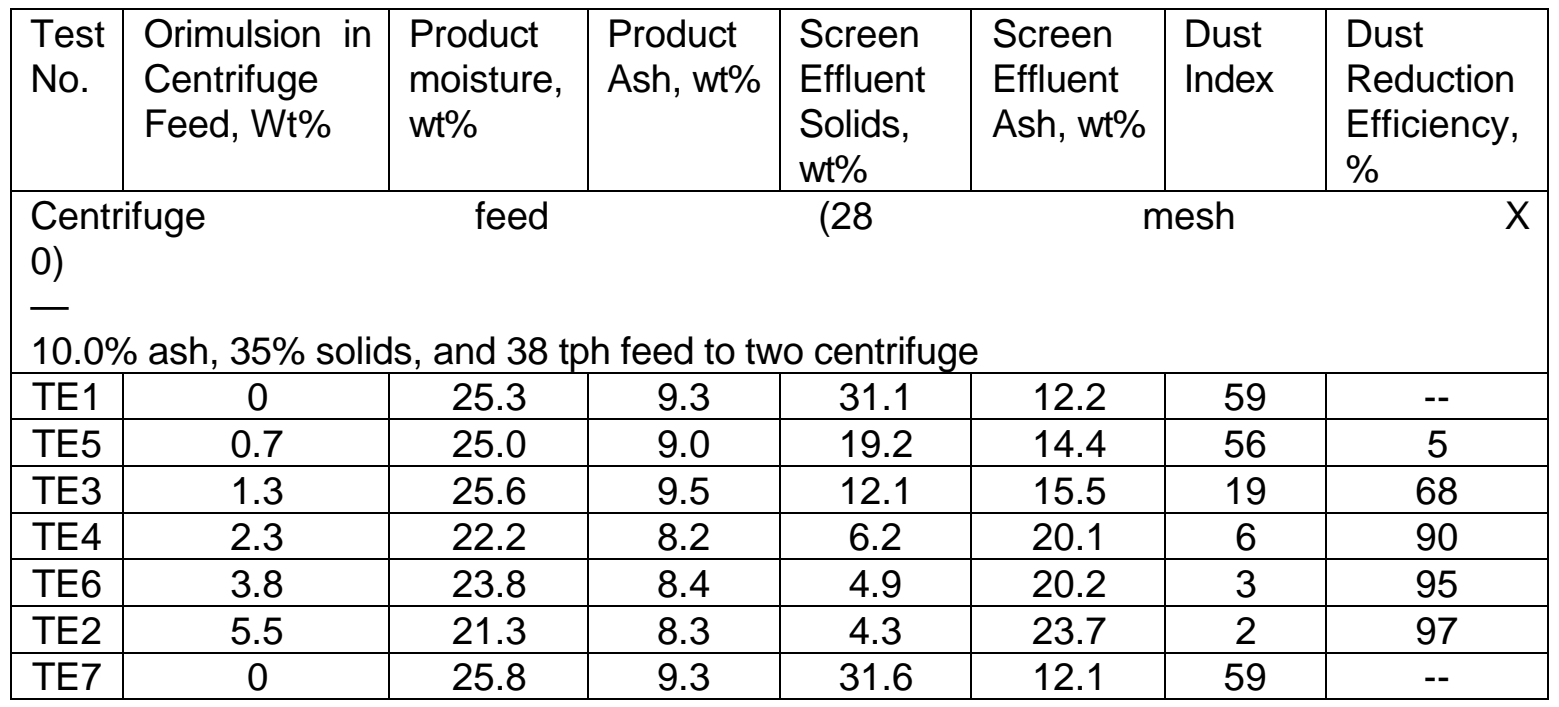

The centrifuge screen effluent solids reduced from 31.1 to 4.3 percent and the ash in the effluent increased from 12.2 to 23.7 percent, with increasing orimulsion dosage from 0 to 5.5 weight percent. The effectiveness of the orimulsion addition on screen effluent solids reduction was very significant, from 
31.1 to 4.3 percent. The screen effluent solids collected showed a color change from black to gray as the orimulsion dosage increased.

The dust index measurement showed that the amount of solids finer than 150 mesh decreased from 59 to 2 weight percent as the orimulsion dosage reached 5.5 weight percent. The dust reduction efficiency was calculated to be $97 \%$.

One of the main concern during the testing was increase of torque in the centrifuge due to orimulsion addition. However, it was noticed that during the two hour test period the torque reading remained low at 37 percent.

The baseline tests were also conducted at the end of testing and the results obtained showed no evidence of centrifuge screen plugging.

\section{Task 7. Evaluation}

The dewatering results obtained with the pilot scale testing at the PMCC Mayflower plant are being evaluated with the help of the equipment suppliers. The goal is to develop economic data on processing of 25 tph of clean coal.

\section{Task 8. Equipment Removal}

Most of the equipment and other accessaries have been removed from the Mayflower preparation plant. The test site has been restored to its original shape. 


\section{CONCLUSIONS}

Based on the vacuum filtration results shown above, the following conclusions are made:

- Use of BASF hydrophobic polymers (Polymin PL and Polymin PR971) had significant effects on cake thickness. Addition of $100 \mathrm{~g} / \mathrm{t}$ Polymin PR971 and Polymin PL increased cake thickness from $5.8 \mathrm{~mm}$ to $10.2 \mathrm{~mm}$ and $8.3 \mathrm{~mm}$, respectively with PMCC low-sulfur fine coal slurry.

- Filter cake moisture obtained with PMCC low-sulfur fine coal slurry was not significantly lowered by use of Polymin PL or Polymin PR971. The moisture reduction was less than one percentage point in most cases. However, use of Polymin PL with PMCC high-sulfur coal showed more significant reduction in cake moisture. Addition of $50 \mathrm{~g} / \mathrm{t}$ Polymin PL reduced cake moisture from $28.3 \%$ to $26.3 \%$.

- Combined use of BASF Polymin PR 971 and Allied Colloids anionic flocculant Percol 156 had almost the same effects on cake moisture and cake thickness as Percol 156 alone was used. This indicated that anionic flocculant Percol 156 played a dominant role in fine coal dewatering and there are negligible synergetic effects between hydrophobic polymer Polymin PL and hydrophilic polymer Percol 156.

Operating conditions including slurry conditioning time, stirrer rotation speed, and vacuum filter drum rotation speed have been examined using a continuous vacuum drum filter for their effects on dewatering of fine coal slurry 
in the presence of polymeric flocculant. Results showed that they have significant effects on solids throughput and cake moisture. Specifically,

- Longer conditioning time had adverse impacts on fine coal filtration. It reduced solids throughput significantly but lowered cake moisture slightly. As conditioning time increased from 3 to 15 minutes, solids throughput reduced from 208 to $111 \mathrm{~kg} / \mathrm{m}^{2} / \mathrm{hr}$ (43 to $23 \mathrm{lb} / \mathrm{ft}^{2} / \mathrm{hr}$ ) and cake moisture decreased from $23.5 \%$ to $21.7 \%$.

- The rotation speed of the stirrer in the conditioning cell significantly affected solids throughput and cake moisture. Too vigorous stirring may break up flocs and insufficient agitation may impede the formation of flocs. An appropriate stirring speed is needed to produce high solids throughput and low cake moisture. For the dewatering system used for the present study $200 \mathrm{rpm}$ stirrer rotation speed provided the highest solids throughput of 208 $\mathrm{kg} / \mathrm{m}^{2} / \mathrm{hr}\left(43 \mathrm{lb} / \mathrm{ft}^{2} / \mathrm{hr}\right)$ and relatively low cake moisture of $23.6 \%$.

- Vacuum drum filter rotation speed had pronounced effects on fine coal filtration performance. Higher drum rotation speed gave rise to lower solids throughput and lower cake moisture. With the use of anionic flocculant and a proper drum rotation speed a cake moisture of about $20 \%$ can be achieved.

- Pilot scale dewatering tests conducted using the DOE/FETC Granuflow Process at the PMCC Terry Eagle plant showed that addition of 5.5 weight percent orimulsion reduced the filter cake moisture from 25.3 to 21.3 percent. The amount of solids lost in the centrifuge screen effluent 
decreased from 31.3 to 4.3 weight percent and ash content of the effluent solids increased from 12.2 to 23.7 percent.

\section{ACTIVITIES FOR NEXT QUARTER}

More laboratory vacuum dewatering tests will be conducted in the next quarter. The efforts will be focused on studies of novel organic chemicals that can displace coal surface moisture and can also be readily recycled. An innovative approach for fine coal dewatering based on surfactant - polymer interaction will also be investigated. Characterization of Orimulsion will be initiated. Otokumpu is in process of supplying us the leaf ceramic filter for testing. We anticipate to start testing with the unit in a short time. 